\title{
Adaptation, Originality and Law: Dion Boucicault and Charles Reade,
}

\author{
By Sarah Meer, University of Cambridge
}

(Article accepted for publication in Nineteenth Century Theatre and Film)

This article explores the legal environment in which nineteenth-century playwrights adapted from French plays and dramatised novels. It suggests that writers and managers tested legislation and created important case-law on adaptation; this was not only expensive but required significant legal knowledge. The essay pays particular attention to Charles Reade and Dion Boucicault, and suggests some ways in which the law relating to adaptation from the French may have affected the practice of adaptation, both from French dramas and from English novels.

Keywords:

Adaptation, Arrah-na-Pogue, Dion Boucicault, Originality, Plagiarism, Charles Reade.

By the end of his career, Dion Boucicault had an unsavoury reputation. In the late 1880 s, his name scarcely appeared in the press without the suggestion that he was too fond of borrowing or imitation, that his success as a playwright had never been fully deserved because his work lacked originality. As a young man in the 1840s, Boucicault had been employed by Benjamin Webster to attend the latest theatrical hits in Paris and produce English versions for the Adelphi in London; this apprenticeship in 'adaptation from the French', his detractors implied, had shaped his practice ever since. If so, Boucicault was the norm, rather than the exception: his career closely coincided with what William Archer dismissed as 'the Adaptive Age', the period between the end of the Licensing Act in 1843 and Arthur Pinero's first plays in the 1880s, when British stages resounded with adaptations from the French, dramatic adaptations from novels, commercial imitations (versions of a play doing well at rival theatres), and provincial piracies of London hits. Meanwhile, American managers 
were putting on British plays without remunerating their authors, and British managers were reciprocating with dramas from New York. ${ }^{1}$

Archer's disparagement of the drama produced in these circumstances set the tone for theatrical histories for nearly half a century, and the critical fortunes of this period have for a long time been closely tied to a relative lack of interest in adaptation, in the conditions that enabled it, in nineteenth-century analyses of it, in its theory and its practice. And yet the persistent sense of unease that attended Boucicault's reputation indicates how much questions of originality mattered in nineteenth-century discussions of the theatre. Adaptation was an urgent subject, as well as a widespread practice, in those mid nineteenth-century years; it occupied legislators and lawyers, and it stimulated analyses of playmaking and theatrical production that offer insights for today's cultural historian into then-current understandings of the play, the novel and national tastes. In several aspects of this, Boucicault is a representative figure: - in the timing of his playwriting career between 1841 and 1890 (reaching his greatest success between the 1850s and 1870s, with a subsequent slow decline), in his facility with French, and his skill at catering specifically for audiences in Britain, Ireland and the United States. As I shall argue, Boucicault also played a crucial part in the legal environment in which adaptations were made and discussed. Ultimately, I shall suggest, he may have been partly responsible for the shift in attitudes that lay behind the increasingly disapproving references to his own work: the man once described as the 'adeptest of adaptors' also helped bring scrutiny to bear on adaptation in his own time, and provides an essential window into its heyday. ${ }^{2}$

Boucicault's reputation had become peculiarly synonymous with shady adaptation as early as the $1860 \mathrm{~s}$. The association was even exploited for publicity, though not by Boucicault himself. In 1864, Boucicault was once again in London after an interval in America. He had formed a partnership with Benjamin Webster in 1860, but this had dissolved in legal disputes over their contractual obligations by June 1862. ${ }^{3}$ However, Webster still owned the rights to an old adaptation of Meleaville's Sullivan that Boucicault had made for him in 1853, and put it on at St James's Theatre in May 1864. The timing was significant: the Haymarket was playing another adaptation of precisely the same French play (called David Garrick), which no doubt inspired Webster to produce 
Boucicault's The Fox Chase. However, Webster added a disclaimer to the playbills, stating that Boucicault had sold the play to him as 'new and original', but had since admitted that it was based on the French play. Boucicault responded with a letter to the Standard stating that he had never thus dissimulated, and that Webster had specifically announced the piece as 'new and original' in order 'to create an occasion to make an apology in the form of the above notice'. ${ }^{4}$ Boucicault did not mention that the play had already been performed in the US in 1853 , and on that occasion he had specifically denied accusations that it was based on Sullivan. ${ }^{5}$

A number of things are striking about the incident. Boucicault's implication is that the apology was designed to attract attention on opening night, by playing on the very similarity to David Garrick that it was ostensibly regretting. The Fox Chase was a commercial imitation, in that it capitalised on the success of one adaptation of Meleaville by staging another. Webster affected shame only about the fact that it was an adaptation; in fact, in doing so, he highlighted the similarity with the success at the Haymarket. Given their estrangement, he probably also enjoyed blaming Boucicault. But the significance given to the word 'original' is worth remarking. Boucicault points out that on the 2 May Webster 'advertised simply “a new comedy," by Dion Boucicault, Esq.'; on the 7 May, when The Fox Chase was due to open, Webster had postponed it for three days, at this point first using the tag 'new and original', 'which announcement he maintained for three days, long enough to enable him to issue the above notice on the day of performance' ${ }^{6}$ Implicitly, 'a new play by Dion Boucicault' would not be taken to mean an 'original' . Most importantly, Boucicault assumes that an 'original', that is a non-adaptation, has some special significance. Boucicault confirms this impression when he cites his payment as contributory evidence that Webster knew it was an adaptation from the start:

In 1853 I offered Mr. Webster an unfinished comedy in five acts, called The Married Bachelor: or, Don Quixote the Second; he lent me 501. upon it; and it is needless to observe that such an amount is a very small part of the value of a "new and original" comedy in five acts, such as Mr. Webster states he purchased under my guarantee. He made no inquiries as to its originality. ${ }^{?}$

This explanation tells us a great deal about the dealings and mutual expectations of playwrights and managers in the 1850 s and 1860 s. A new play was not necessarily an original; managers did not expect the former to be the latter, and prices were structured 
accordingly. Arguably, Webster was even stretching the truth with the word 'new', since he had been sitting on the play for eleven years. Having bought it when Boucicault was still making his way and selling his plays outright for modest sums, Webster was bringing The Fox Chase out at a time when Boucicault had had a string of successes in New York, then London and Dublin, and was able to charge nightly royalties for the use of his plays. The final point of interest is that the audience protested, not at the adaptation, but at the controversy: one section hissed the management for having 'done all it could to damage the chances of the play', the other turning on the first hissers, 'believing that the row was got up by parties sent in for the purpose' (presumably they were taken for partisans of Boucicault). ${ }^{8}$

The following year, J. Arnold Cave, the manager of the Marylebone Theatre Royal, advertised his unauthorised production of Boucicault's The Octoroon as 'by Dion Boucicault, whose adaptations from the French stage have obtained for him so much notoriety'. ${ }^{9}$ Although Boucicault complained in print of Webster's treatment, and consulted his lawyer about responding to Cave, audiences' good-humoured responses to the abuse of his reputation suggest tolerance for, and even enjoyment of the ironies produced by the culture of adaptation. ${ }^{10}$

This was as true in the United States as in Britain. In 1874, the New York Herald produced a particularly elaborate example of the inoriginal Boucicault story, one that emphasised his success, and enveloped his iffy standing in an atmosphere of knowing, masculine bonhomie. The Herald reported that it had sent a writer to interview some men of the theatre on the topical controversy: was the author of Shakespeare's plays really Francis Bacon? At Dion Boucicault's fashionable residence, enviably located between Tiffany's and the Manhattan Club, the Herald's man found Boucicault sharing champagne cocktails and cigars with the writer Bret Harte and actor-manager Howard Paul. The Herald's man put the question: 'who wrote Shakespeare: was it Bacon?' Paul said no, it was Boucicault; Harte declared, 'I was there when he did it', and not only that: 'they were adaptations from the French' ${ }^{11}$ In aligning Boucicault with the disputed provenance of the immortal Shakespeare, Harte seems at once to relish Boucicault's infamy, to ridicule the Bacon theory, and, slily to imply that the theatre business has always been attended by question-marks. 
And yet there were already signs of a more clear-cut and censorious attitude developing: in February 1875, a Chicago paper included a small piece on the enormous gross receipts Boucicault was said to have raised on his most recent plays, and commented succinctly (and inaccurately, in the cases of Arrah-na-Pogue, and The Shaughraun, which were not adaptations): 'Plagiarism pays'. ${ }^{12}$ William Winter's review of Boucicault's 1873 comedy Led Astray gives a sense of mixed, or shifting, attitudes to adaptation. Winter declared Boucicault's treatment of the play's origins to be an example of 'with what an assured step clever authorship can walk on ticklish ground.' When Boucicault was called before the curtain at the end, he made a speech in which 'he told his auditors to give at least two-thirds of the credit for whatever pleasure thay had received to his friend Octave Feuillet. ${ }^{, 13}$ This in itself suggests a slightly more developed notion of dues towards the French author than that of earlier decades, but it was not enough for the younger critic Winter (born 1836): 'the appearance of Octave Feuillet's name upon the playbill would be noted with satisfaction. Mr. Boucicault should be aware that, by lapses of this kind, he arms his detractors and is unjust to himself. ${ }^{14}$ In 1886, Brander Matthews observed both an epidemic of accusations of plagiarism and a decline in adaptation: 'now when a French drama in an English or American theatre generally bears the French author's name, and when the best work of the best English dramatists is really their own'. ${ }^{15}$ By the time Boucicault died in 1890, some obituaries had made his name a verb denoting pilfering ('Boucicaulted the characters and the story'), while David Belasco later claimed that when he worked as Boucicault's amanuensis in the 1870s, Boucicault dictated a comedy between surreptitious glances at a French text. ${ }^{16}$

Yet though the later nineteenth-century assessments of Boucicault's career pronounce its reliance on adaptation regrettable, even they emphasise his skill at it. Belasco argued that 'He left everything better than he found it; his pen was often inspired'; while William Winter's lukewarm assessment nevertheless admitted Boucicault's dramatic instinct - 'He possessed the art of making his interlocutors speak in character, and sometimes he devised remarkably fine, because dramatically, rather than verbally, expressive stage business and effect' ${ }^{17}$ Even as Boucicault's dramatic practices came to look dated and distasteful, they were still not dismissed out of hand, and this was partly because his adaptations highlighted the different requirements of the dramatic and narrative arts. The critic who signed himself ' $Q$ ' in the Athenaeum in 1870 was far from approving in many respects, but he acknowledged Boucicault's 'constructive skill', 
admitted that '[n]o man is more happy in dialogue, [both] drolleries and delicacies in expression', and defined 'what he himself adds' to French pieces as 'theatrical tact'. ${ }^{18}$

Questions of originality and its converse, plagiarism and piracy, were thus raised and considered with some heat, even during the period when adaptation and appropriation were rife in British and American (and, it must be said, Canadian and Australian) theatres. And yet the academic investigation of the relations between discourse, practice, and the legal environment of nineteenth-century adaptation has been relatively scanty. Philip Cox's important book on Romantic adaptation draws on John Ellis's thinking about modern film adaptations, but the analogy with modern adaptation practice seems to me to be an unnecessarily indirect approach to nineteenth-century understandings of generic transformation. It is worth listening to nineteenth-century articulations themselves, particularly as mid-nineteenth-century discussions, even of novel dramatisation, were quite deeply inflected by the ubiquity of adaptation from the French (issues of language and nation are not usually so prominent in thinking about film adaptation).${ }^{19}$ Philip Bolton's painstaking attention to the dramatisation of Dickens and Scott also takes a retrospective position on some of these questions - '[o]riginality and proprietorship seem to be values and practices of later times' - although Bolton does note many of the contradictions that characterised the special indeterminacy of the moment, for example that dramatisations tended 'to occur in clusters, mutually inspired, mutually competing, and mutually benefiting from that competition. ${ }^{20}$

Meanwhile, some literary critics' investigations of notions of originality in the period have ignored the theatre entirely, and arguably skewed their findings as a result. Robert Macfarlane's argument in Original Copy is for a movement away from the idealisation of originality in the nineteenth century, towards the bricolages of modernism and beyond: 'from the late 1850s onwards, unoriginality - understood as the inventive reuse of the words of others, came increasingly to be discerned as an authentic form of creativity. ${ }^{21}$ Although one of Macfarlane's chapters is devoted to Charles Reade, he only addresses Reade's playwriting glancingly, noting that Reade 'translated and adapted for the English stage, almost always without permission'.22 As I shall suggest, this is a misleading summary, since Reade's adaptation from the French was not only a common practice protected by legislation but a practice he sought to reform in favour of the rights of French authors. In a series of lawsuits and subsequent writings that I shall discuss, Reade made a 
highly public performance of gaining permission for one dramatisation, which demonstrated (and was partly designed to demonstrate) that the law was weighted in favour of unauthorised representation, rather than protection of authors or approved translators. Macfarlane's lack of interest in Reade's work for the stage may be justified in terms of Reade's relative spheres of impact, since he was probably best known in his time for novels like It Is Never Too Late To Mend, but Reade himself insisted that his epitaph declare him a playwright first: 'Dramatist, Novelist, and Journalist'. ${ }^{23}$ More importantly, even a cursory consideration of Reade's theatrical involvement - his adaptations, his journalism, and above all his stage-related litigation - would contradict the impression that Reade believed the attribution of adaptations was unimportant. On the contrary, his career, like Boucicault's (with which at some points it was closely connected), suggests an evolving relationship with adaptation, in which the movement was more towards an emphasis on originality than away from it. Admittedly, Reade was often self-serving and unscrupulous, but as I shall suggest, some of the inconsistencies of Reade's attitudes towards authorship, like Boucicault's, reflect the theatrical norms and the legal conditions in which they worked. Alan Ackerman asserts that 'the intensifying debate over plagiarism later in the century indicates the heightened tension between a "literary" view of the drama and a view of drama shaped by the exigencies of producing theater', but this seems to me to institute a distinction between the literary and the theatrical that nineteenth-century playwrights would have rejected, while the cultural tensions at stake stretched well beyond the literary status of theatre. ${ }^{24}$ Mark Rose has argued that it is a mistake to judge the British copyright legislation of the 1770s in the light of the sense of intellectual property that has been established in the subsequent two hundred years, that eighteenth-century arguments 'should not be understood as a particular logical failure ... but rather as a significant vagueness, one that very precisely preserves the blindnesses, the strategic indecision [of that period's version of possessive individualism]'. ${ }^{25}$ Adaptation was similarly a site of significant vagueness in the mid-nineteenth century, and its blindnesses, its areas of indecision, and nineteenth-century attempts to overcome them were more complex and ultimately more important than we have acknowledged.

Legal historians argue that for several decades in the mid-nineteenth century many people felt that literary and theatrical creation deserved more legal protection, but the difficulty of settling the variety of implicated interests obstructed the necessary agreements. According to Gavin Macfarlane, 'there was general dissatisfaction with the 
whole condition of the law of copyright. ${ }^{26}$ In Britain, Catherine Seville argues, 'the need for a coherent approach to copyright, preferably embodied in a single act, was clear for much of the century ... [but while] effort after effort was expended on copyright reform', a satisfactory situation was not reached until the International Copyright settlement of 1911. ${ }^{27}$ Nineteenth-century commentators themselves regularly charted the history of copyright law and its anomalies, Charles Reade doing so on more than one occasion. ${ }^{28}$

The legal protection of plays developed piecemeal, slowly, and much later in the Anglophone world than in France. The 1833 Dramatic Copyright Act gave British authors the sole right in any unpublished play, and the "sole liberty of permitting its representation':- what are now called 'performance rights' (or what were often known in the nineteenth century as stage rights). The protected period lasted twenty-eight years from the date of publication, or the residue of the authors' life, and protection extended throughout Britain and Ireland. ${ }^{29}$ The act enabled the Dramatic Authors' Society, formed in 1832 and inspired by the French Société des Auteurs et Compositeurs Dramatiques, to set up a system for the collection and distribution of payments from managers to playwrights, taking in London and provincial managers and even amateurs. ${ }^{30}$ Nevertheless, until 1842 , playwrights' contracts with the non-licensed theatres were vulnerable, since arrangements to perform unlicensed drama might be held illegal in the courts. The 1842 Copyright Act extended the terms for copyright and performance rights to forty-two years, or seven years after the death of the author. ${ }^{31}$ But these protections only applied to the plays of British authors, which had to be first produced in Britain and registered at the time according to specified procedures. In the United States, dramatic authors acquired stage rights in an 1856 Act of Congress, but the law only applied to American authors, and again, only provided that they followed specific registration requirements. ${ }^{32}$ An Anglo-French convention in 1851 produced a further International Copyright Act in 1852, whose particular application to the theatre was that it protected French authors who registered their works in Britain, which in theory gave them rights over translation. However, the Act soon became notorious for the clause that excluded from protection 'fair Imitations or Adaptations to the English Stage of any Dramatic Piece ... published in any Foreign Country' ${ }^{33}$ This clause was understood by the courts to leave adaptation from the French unimpeded, and it was not removed until the International Copyright Act of $1886 .{ }^{34}$ Reciprocal copyright protection between Britain and the United States was not achieved until $1911 .^{35}$ 
But legislation was only part of the picture. As John Russell Stephens remarks, 'case law was just as influential as the reforms initiated by Parliamentary process'; it was the willingness of writers and managers to test that legislation in the courts that helped establish the extent to which these laws acknowledged the importance of originality in dramatic works, and also the limitations of their acknowledgement. ${ }^{36}$ It was no accident that the Era and the Entr'acte carried reports of theatrical lawsuits. ${ }^{37}$ It was not merely stage gossip or an anxiety to record the doings of prominent personalities: if it was worthwhile for an individual to take a matter to court, the outcome often had substantial implications for the profession as a whole.

Charles Reade was one of those individuals. Reade had read law at Lincoln's Inn between 1838 and 1842 as part of the qualification for his Oxford college fellowship; he put that legal knowledge to good use in the 1850s, initiating proceedings in several important cases that one biographer dubs 'a crusade against piracy', and he wrote about these cases, in one instance at enormous length. ${ }^{38}$ He claimed that the litigation that addressed the 'fair imitations or adaptations' clause turned his hair grey. It involved a play by Edouard Brisebarre and Eugène Nus called Les Pauvres de Paris, and lasted from February to May 1857. Acting as he thought in the spirit of the 1852 Act, Reade treated with Nus for the sole right of translation and production in England in return for half the proceeds. He printed his adaptation, Poverty and Pride, and registered it at Stationer's Hall. Reade also rather muddled the issue by taking $£ 20$ from William Creswick to allow J. Stirling Coyne's adaptation, Fraud and its Victims, at the Surrey Theatre, but he took issue with another adaptation, which neither offered the French authors compensation, nor recognised the rights Reade had acquired, while trading on his title. Benjamin Barnett and John Beere Johnstone's The Pride of Poverty, or the Real Poor of London appeared at the Strand, managed by Thomas Payne. Reade threatened to sue Payne in the pages of the Era, and was then sued himself, by Payne and also by Barnett and Johnstone, for thereby injuring their reputations. Although Reade's stand was applauded and partly funded by French writers, including Brisebarre and Auguste Maquet, president of the Société des Auteurs et Compositeurs Dramatiques, it was expensive and unsatisfactory in its outcomes. As the critic for the Era pointed out, Reade's complaint worked as publicity for the Payne version, which filled the house in consequence. Reade's attendance at the Strand, flanked by two shorthand writers to take down the dialogue for the purposes of comparison, was itself an attraction for the audience, and duly remarked upon by the Morning Chronicle's 
reviewer. ${ }^{39}$ Reade sued Payne in the County Court, hoping to win a judicial ruling in his favour without running up huge costs on either side - he calculated that he would lose his own costs either way, since Payne was 'virtually insolvent' ${ }^{40}$ Payne successfully applied for the case to be moved to the Court of Exchequer; Reade, deciding it was not worth the financial risk, gave his suit up. Then Barnett and Johnstone's suit against Reade was heard at a court in Croydon. Johnstone testified that he could not read French, and had worked from a translation by Barnett, 'and [created] new characters and scenes, so as to make the piece almost an original piece'. ${ }^{41}$ Johnstone and Barnett's case was nonsuited (they were deemed to have failed to make their case that Reade had damaged their interests). However, Reade was frustrated by this outcome, as he wished to demonstrate in court that, having paid for it, he alone had the right to Nus and Brisebarre's plot in Britain. Moreover, Reade's legal bill for Reade v. Payne; Payne v. Reade and Barnett and another v. Reade came to $£ 270$; although Reade was awarded costs, Payne went bankrupt and evaded payment. Barnett also threatened to go through the insolvency courts, and Reade settled with him for $£ 60$ paid by instalments. Johnstone he took pity on, as 'a poor actor', so overall Reade shared the brunt of the expenses with the Société des Auteurs, without managing to make a satisfactory stand against the 'fair imitation' clause of the 1852 Act (which his opponents were invoking). ${ }^{42}$ All this activity, in the papers, in the theatre and in the courts, did, however, produce commentary on the adaptation question, including some as condemnatory as what Bolton calls the 'values of later times' would demand. In the Morning Chronicle, 'Dramaticus' hoped the case would bring about satisfactory International Copyright, which would abolish unacknowledged adaptation: 'the common charlatan practice nowadays for a man to lay violent hands on a French piece, translate it, and deliberately and unblushingly put it forth as his own composition' ${ }^{43}$ Reade contented himself by laying out the argument he would have made in his account of events in The Eighth Commandment, together with witness testimony, documents, and a side-by-side comparison of sections of his play and the Strand's. ${ }^{44}$ This argument is of interest, not only because it demonstrates the importance Reade attached to giving French playwrights their due, but because it amounts to a theory of adaptation, in which Reade insists that plot is a central part of what adaptors borrow, and also that plots can have French characteristics. Reade writes that if he had been able to argue his case in court, he would have produced,

[t]wo witnesses to prove that the plot is the soul of a play; that what the public goes to see at a theatre is a new plot or an incarnate story: and the newspapers, who 
always know what the public wants to hear, confine their description of a new play to an analysis of the plot and characters. ${ }^{45}$

Next, Reade wished to call on the American dramatist Bayle Bernard,

who has both written original plays, and adapted from the French, to depose that he has carefully compared the two pieces, and thinks that, as far as phraseology, the plaintiffs' is certainly not a translation but an adaptation .... Mr. Bernard maintains that there is such a thing as translation of incidents; and that, in particular, to transfer a modern characteristic French incident to the English stage is to distort the English stage to the French incident, not adapt the French incident to the English stage. ${ }^{46}$

By characteristic French incidents, Reade means those culturally specific aspects of the plot of Pauvres that do not translate well to an English context. Reade draws attention to these elements because he believes that extensive borrowing from the French is damaging the realism of the British stage, since there are in consequence numerous depictions of 'French truths, but English lies and absurdities'. ${ }^{47}$ But naturalising or Anglicising the incidents of a drama was also a vital component of 'fair imitations and adaptations'. In Wood v. Chart (1870), the Vice Chancellor spelt out the difference between adaptation and translation: 'he has introduced English characters; he has transferred the scene to England; he has made the alterations necessary for adapting it ... and he has left out a great number of speeches and passages .... ${ }^{48}$ Anglicising characters, setting, incidents and dialogue was an essential aspect of adapting from the French, not only to please audiences, but also to ensure that the adaptation did not infringe the Copyright Act of 1852. The implications of French-adaptation for the dramatisation of novels have yet to be fully investigated, but the institutionalised latitude of the first no doubt widened the range of possibilities for the second. Dramatised novels could benefit from the reflected glory of the original, which in effect publicised the play, but this did not always mean that fidelity to the novel was prized, or even demanded, by audiences. The New York critic Brander Matthews considered the practice in 1889 , noting the need for 'more careful and elaborate structure in a play'. ${ }^{49}$ Matthews suggested an ideal method of dramatisation that sounds very like Johnstone dramatising a play from Barnett's rough translation: 'the story is perhaps best set on the stage by a playwright who has never read it'. Matthews' example also involves translation, but in this case, into French: Eugène Nus explained that his version of East Lynne derived from an actress's casual summary in conversation of Mrs Wood's novel. ${ }^{50}$ 
As I have suggested, Charles Reade had generated important case law in relation to adaptation from the French, which highlighted the consequences of the 'fair adaptation' clause for the rights of French authors, and also for translators and adaptors who intended to work with those authors in good faith. Reade also launched litigation that helped clarify the position on adaptation from novels, and helped establish the current limitations of the law from the point of view of novelists. In the unusual position of having first produced a play, Gold, in 1853, that he then turned into the novel It is Never Too Late To Mend (published 1856), Reade was able to sue the publisher William Hailes Lacy for printing an unauthorised play text of It is Never Too Late (dramatised by Colin Hazlewood), and the managers Benjamin and George Conquest for producing a dramatic version at the Grecian Theatre. As Malcolm Elwin concluded, Reade's elaborate preparations for these cases, which involved cutting and annotating legal papers dating back to 1837 , and compiling a list of London's staged adaptations between 1660 and 1815, indicate that his litigation was intended to create important precedents: 'to secure justice, not merely for himself, but all victimised authors afterwards' ${ }^{51}$ Reade sued for the infringement of copyright in both Gold and It is Never Too late to Mend; Lacy's printed play was found to be an infringement; the Conquests' performance was found to have infringed the copyright of Gold, but not of the novel. ${ }^{52}$ Reade had established in this way that the law protected the work of British playwrights but not novelists (and as a result some novelists began to preempt unauthorised dramatisation by producing their own to coincide with publication) ${ }^{53} \mathrm{~A}$ few years later, Reade's friend Dion Boucicault would take to the courts to tackle the process in reverse, the novelisation of original plays.

Reade and Boucicault were both members of the Garrick Club, but they seem to have been personal friends from at least 1864. Boucicault too had adapted Les Pauvres de Paris, though as he was then in the United States (his 1857 version was initially called The Poor of New York) it did not become entangled in the Payne controversy, and there is no evidence that Reade objected when in 1864 Boucicault took the relocation principle of French-adaptation to a provincial extreme, refashioning the play as The Poor of Liverpool, The Poor of Leeds, The Poor of Manchester, and The Streets of London. ${ }^{54}$ In 1868, the two writers collaborated on a drama and a novel - Foul Play - published first as a serial in Once $a$ Week, and then in three volumes by Bradbury and Evans. This project was itself soon overtaken by a plagiarism scandal, though in this case the allegation was that the British authors had made an unacknowledged adaptation from La Portefeuille Rouge, an 
1862 drama by Henri-Horace Meyer. Reade published an elaborate defence of Foul Play in Once a Week, comparing in detail its characters, incidents and dialogue with that of $L a$ Portefeuille. ${ }^{55}$ The impression he gives is less vindicating than he would have liked, since his own examinations of adapters from the French had already testified to the loose way in which adapters traditionally worked with originals, in many cases like Johnstone working at second-hand through a translation. ${ }^{56}$ In that context, it is not entirely reassuring when Reade asserts that he had never seen La Portefeuille until he heard the allegation, and if the single 'valuable situation common to both works' came to him from Boucicault, 'it came in conversation' ${ }^{57}$ The analysis suggests that some incidents look similar, though they are given different weight in the British and French work, but there seem to be no debts in the dialogue. Reade's detailed inventory of characters is very interesting, however, both in that it does seem to offer a basis of comparison, and because it appears to show that the English versions have turned melodramatic traits into sentimental ones, and converted French ideas of femininity into nineteenth-century British ideals. In parallel columns, Reade sums up the respective French and British characters. Number 2 in Le Portefeuille is 'De Folbert ... the trite monster of Melodrama, that never existed in nature'. Reade and Boucicault's number 2 is, 'Young Wardlaw, a weak youth, led into crime by cowardice; a knave tortured by remorse and rendered human by an earnest love' ${ }^{58}$ The French character is a standard villain, in other words; the English one a flawed moral being, who is seen to evolve. In one case, a similarity of name looks damning, but it is mitigated by the fabled Anglo-French divide on feminine morality. The French number 12 is

Hélene, ... a weak, amiable girl, who parts with her virtue the first fair opportunity. This character is indistinguishable from a thousand others in French fiction.' 59 The English number 6 is

'Helen ..., a young lady of marked character, hard to win and hard to lose, virtuous under temptation, and distinguished by a tenacity of purpose which is rarely found in her sex. Upon the whole, a character almost new in fiction. ${ }^{60}$

It is, in other words, the French playwright whom Reade charges with inoriginality, for producing the 'trite monster of Melodrama' and a heroine 'indistinguishable from a thousand others' (unsurprisingly no better than she ought to be), while in his account Reade and Boucicault have produced complex characters, who are new, or 'almost new' in 
fiction. Almost new was good enough for Reade: "no honest and discerning man can believe the writer ... [of] Foul Play had his eye on the drama' ${ }^{61}$

Although Reade by far outproduced Boucicault in journalism, Boucicault rivaled him as a litigant. William Brady's Boucicault testimonial suggests how much Boucicault valued legal savvy: Brady made the mistake of producing Boucicault's After Dark (1868) in San Francisco from a pirated manuscript. To Brady's horror, Boucicault himself turned up and accosted him. Brady paid $\$ 1100$ dollars for the rights; he soon concluded that it was 'the worst pup I was ever sold in the course of a highly checkered career', because Augustin Daly had already proved in the courts that Boucicault had stolen a scene from Under the Gaslight, and Brady had let himself in for thirteen years and thousands of dollars fighting Daly, fruitlessly, to the United States Supreme Court. ${ }^{62}$ The sinister phrase with which Boucicault initially taxed Brady is telling: 'Your legal education has been neglected, Mr. Brady'. ${ }^{63}$ The complexities of theatrical copyright, especially international copyright, made a fair knowledge of the law a necessity for managers and playwrights.

Boucicault's familiarity with the lawcourts is suggested by his portrayal of the criminal barrister in his The Trial of Effie Deans (incidentally an adaptation of Scott's The Heart of Midlothian). The Times admired Boucicault's 'arts and contrivances proper to a first-rate criminal practitioner', his 'whisperings to the junior counsel, the sneers at the Crown lawyer, the eager grasp at expedience suggested by the exigencies of the moment, the bursts of tricky eloquence' ${ }^{64}$ No wonder. The standard US treatise on copyright in the nineteenth century was an 1879 book by Eaton Sylvester Drone, $A$ Treatise of the Law of Property of Intellectual Productions in Great Britain and the United States. ${ }^{65}$ No fewer than five of the cases that Drone cites as demonstrating or deciding aspects of copyright are ones in which Boucicault was the plaintiff: Boucicault v. Fox (1862); Boucicault v. Delafield (1863); Boucicault v. Wood (1867); Boucicault v. Hart (1875); and Boucicault v. Chatterton (1876). These cases deal with performance rights over an unpublished drama in the US; copyright in Britain of plays first performed in the United States; copyright protection in the States for plays by a resident non-citizen. Most pertinently for our purposes, Boucicault v. Fox concluded in the US that, 'a play may be original, although its characters and incidents are similar to those of a previously published novel' ${ }^{66}$ Where Reade did his 
utmost to prevent dramatists adapting novels without permission, Boucicault helped enable the practice in the United States.

However, in Boucicault v. Berger, 1865, Boucicault sought an injunction to prevent the novelisation of his own original play Arrah-na-Pogue. Boucicault had produced Arrah in Dublin in November 1864, and then opened a new version at London's Princess's Theatre on 22 March 1865. The play was hugely popular in both cities, and was also translated into French as Jean La Poste ${ }^{67}$ In this Irish drama set just after the 1798 rebellion, the peasant girl of the title hides an aristocratic rebel, and her fiancé takes the blame in a comic court-scene, wittily destabilising the strait-laced British. It was presumably the success of this production that prompted Joseph Berger to put his own prose Arrah on the front page of the penny weekly the London Herald on or before 22 April. Berger belonged to a family of radical booksellers: his father George had been among the group who pirated Dickens' A Christmas Carol in 1844, and threatened Boz with a beating. ${ }^{68}$ Joseph sailed similarly close to the wind. Before he took over the Herald, he had already been bankrupted in 1858: this would be the first of three insolvencies. ${ }^{69}$ Berger's four-part narrative Arrah only ran to twelve pages, of which four half-pages consisted of illustration..$^{70}$ If anything, the tale contains less text than the play, and is more fragmentary, though it was possibly truncated so as to finish it before the courts could. Of thirteen chapters, the first nine adapt Boucicault's Act I; Berger then skips most of Acts II and III, including the sensation scenes (the court martial and a prison-break), coming to a sudden stop. He draws heavily on Boucicault's incidents and often echoes his dialogue, but simplifies it, losing the witty quips. Perhaps in keeping with the Berger family's radical sympathies, the tale is more overtly political in its references to Irish history than Boucicault's play.

Boucicault wrote to Berger as soon as he saw it: 'This publication is a piracy on my work ${ }^{71}$; when there was no reply, he contacted his solicitor, George Carew. Carew wrote in his turn to Berger, who prevaricated, saying that 'it would be next to impossible to withdraw the tale now', and arguing that his tale would act as publicity for the play. ${ }^{72}$ Carew insisted, Berger replied that he had ordered 'immediate discontinuance' of the piece, but he still sold a further two instalments, prompting Boucicault to seek an injunction to stop further printing, publishing or selling of his 
tale. $^{73}$

The Bill of Complaint shows that a detailed comparison took place in Chancery of the play and Berger's tale, the corresponding parts of which were printed side by side in the Bill, and some of this was subsequently reproduced in The Times. ${ }^{74}$ This was forensic textual criticism, in which Boucicault sought to demonstrate correspondences in the title and names of characters, 'descriptions of scenes', and events 'mentioned in the same order and succession'. Moreover he asserted that the language 'closely resembles it and is in many parts the same', with any differences due merely to the generic demands of the form: 'consequent upon one publication being a dramatic piece and the other a novel or tale'. ${ }^{75}$ The Vice Chancellor agreed, granting the injunction on 11 May and concluding that 'there had been a manifest wrong against the plaintiff, without any excuse'. He stipulated that Boucicault must give security for any damages that might arise over the question whether "the publication in America on the same day sufficiently complied with the requirements of the Act, that a "book should not have been previously published in any foreign country", ${ }^{76}$ But like Reade's over Payne in 1856, Boucicault's victory was pyrrhic, because Berger changed his lawyer to stop Boucicault serving him with the costs, and was next heard of in Whitecross gaol, declared bankrupt. Berger's lawyer informed Boucicault's 'that the only loss [Berger] could now sustain would be from not being able to sell the back numbers to casual customers which would be very trifling. ${ }^{77}$

These proceedings were expensive. We have unusually detailed evidence, since Carew's invoice for the years 1864-6 survives. Carew's charges relating to Boucicault v. Berger were $£ 23610 s 4 d .{ }^{78}$ The invoice shows Boucicault's assertiveness about his proceedings, and that he had an eye on protecting his rights in the play that extended well beyond Berger. He insisted against his lawyer's advice that the Bill refer to the revised version of Arrah, and that the suit must involve John Henry House, to whom Boucicault had assigned the US rights (taking care to conduct this legislation in London in a way that would not deprive him of rights in New York). ${ }^{79}$ After the injunction, Boucicault insisted on discussing the implications, not only with his solicitor and his barrister Mr Dickinson, but with Sir Hugh Cairns, QC, the Solicitor-General (who in 1868 would become Lord Chancellor), at a cost of $£ 30$ $6 s 4 d$, and he spent another $£ 55 s$ on assigning the American rights to House. ${ }^{80}$ 
Carew's invoice indicates that Boucicault took part in detailed discussion, even of the phrasing of copyright acts:

1865, May 11: Attending you in conference discussing the questions that had arisen both with Counsel and the Vice Chancellor on the hearing of the Motion for an Injunction in your suit against $\mathrm{Mr}$ Berger as to what amounted to publication \&c and as to the conflict between English and American rights and referring to the Copyright Amendment Act of 5 and 6 Vict: 45 which clearly indicated that representation of a Drama was equivalent to publication which you considered had not been understood and you being desirous of having that point settled wished me to draw out a statement to Counsel for an Opinion [£5 6s 8d]

...

May 19 ... Attending you thereon and discussing the matter and investigating the two acts of Parliament upon which we put different constructions and you determined on taking the opinion of Sir H Cairns after the conference with Mr Dickinson [1£ 6s 8d (my emphasis)]

Note 'upon which we put different constructions'. On the 14th June, Berger similarly records Boucicault, 'not concurring in the opinion'. In Carew's billing for this and other cases, we can see that Boucicault was willing to spend very large sums of money on protecting the rights to his plays on both sides of the Atlantic, and that he took an active and knowledgeable part in that legal work. In doing so he was not only warning off would-be adaptors of the future, he was testing the protection afforded by legislation. He was defining what was 'fair imitation or adaptation', and what was piracy. I want to suggest that it was partly because Boucicault was willing to take these expensive risks that he appears so frequently in Drone's Treatise. To stretch the point still further, Boucicault's litigation, like Reade's, is an indication that some of the nineteenth-century's significant work for the theatre took place in court, where the ethics of adaptation were in the process of being examined and established. The gap between Boucicault's increasingly nefarious reputation and the legality of his practice reflects some of the anomalies of copyright legislation before 1911, and his own finetuned sense of those anomalies. In this he was not unlike his own Irish scamp in 
Arrah-na-Pogue: when Shaun the Post is asked in court if he is 'guilty or not guilty', he replies: 'How would I know till I hear the evidence? ${ }^{\text {81 }}$

${ }^{1}$ William Archer, The Old Drama and the New: An Essay in Revaluation (London: William Heinemann, 1923), p. vii.

${ }^{2}$ Anthony Jenkins, The Making of Victorian Drama (Cambridge: Cambridge University Press, 1991), p. 25.

${ }^{3}$ Richard Fawkes, Dion Boucicault: A Biography ([1979] London: Quartet, 2011), pp. 120-32,

${ }^{4}$ Dion Boucicault, 'The Fox Chase', The Standard, 16 May 1864, p. 2.

${ }^{5}$ Fawkes, p. 81.

${ }^{6}$ Ibid.

${ }^{7}$ Ibid.

8 'Boucicault's New Comedy', Boston Daily Advertiser, 31 May 1864, p. 2.

9 'Theatre Royal, Marylebone', The Times, 27 March 1865, p. 8. The Octoroon was not copyright in Britain, because first performed in the US; it is thought to have been adapted from Mayne Reid's 1856 novel The Quadroon, not a French play.

${ }^{10}$ Letter to the editor, Standard, 16 May 1864; University of Kent, Calthrop collection, uncatalogued manuscript, deedbox marked FLJ: George Carew's invoice to Boucicault, 1864-6 (hereafter Carew, invoice).

11 'As to Shakespeare', reprinted Milwaukee Sentinel, 14 September 1874, p.2.

${ }^{12}$ [no title], Inter Ocean, 9 February 1875, p. 7.

${ }^{13}$ William Winter, review of Led Astray, New York Tribune, reprinted in The Life of David Belasco ([1918], Freeport, NY: Books for Libraries Press, 1970), pp. 59-60, p. 59.

${ }^{14}$ Ibid., p. 60.

${ }^{15}$ Brander Matthews, 'The Ethics of Plagiarism', Longman's Magazine, October 1886, p. 630.

${ }^{16}$ University of Kent, Canterbury, 648426, clipping, Stephen Fiske, 'Spirit of the Stage', Spirit of the Times, 27 September 1890; see Winter, Life, pp. 55-7.

${ }^{17}$ Belasco quoted in Winter, Life, p. 57; William Winter, Other Days: Being Chronicles and Memories of the Stage (New York: Moffat, Yard, 1906), p. 133.

18 'Q', 'Dramatists of the Present Day II Mr Dion Boucicault', Athenaeum, 3 December 1870, pp. 730-1.

${ }^{19}$ Philip Cox, Reading Adaptations: Novels and Verse Narratives on the Stage, 17901840 (Manchester: Manchester University Press, 2000), p. 2. 
${ }^{20}$ H. Philip Bolton, Dickens Dramatized (London: Mansell Publishing, 1987), pp. 14, 13. He also briefly remarks that 'Charles Reade contributed greatly to the redefinition of dramatic authorship' (p. 14), a point I hope to amplify below.

${ }^{21}$ Robert Macfarlane, Original Copy: Plagiarism and Originality in NineteenthCentury Literature (Oxford: Oxford University Press, 2007), p. 8.

${ }^{22}$ Ibid., p. 130.

${ }^{23}$ Malcolm Elwin, Charles Reade, ([1931] New York: Russell and Russell, 1969), p. 357.

${ }^{24}$ Alan L. Ackerman Jr., The Portable Theater: American Literature and the Nineteenth-Century Stage (Baltimore: Johns Hopkins University Press, 1999), p. 3.

${ }^{25}$ Mark Rose, 'The Author as Proprietor: Donaldson v. Beckett and the Genealogy of Modern Authorship', in Brad Sherman and Alain Strowel (eds), Of Authors and Origins: Essays on Copyright Law (Oxford: Clarendon Press, 1994), p. 50.

${ }^{26}$ Gavin Macfarlane, Copyright: the Development and Exercise of the Performing Right (Eastbourne: John Offord, 1980), p. 61.

${ }^{27}$ Catherine Seville, 'Copyright', in David McKitterick (ed.), The Cambridge History of the Book in Britain Vol VI (1830-1914) (Cambridge: Cambridge University Press, 2009), pp. 214-5. Her argument is developed in more detail in The

Internationalisation of Copyright Law: Books, Buccaneers, and the Black Flag in the Nineteenth Century (Cambridge: Cambridge University Press, 2006).

${ }^{28}$ Charles Reade, The Eighth Commandment (Cambridge: Welch, Bigelow, 1860), passim; Charles Reade, 'The Rights and The Wrongs of Authors', Pall Mall Gazette, 15 July-18 September 1875; James Neville Porter, Macmillan's Magazine, 40 July 1879, pp. 244-246.

${ }^{29}$ John Russell Stephens, The Profession of the Playwright: British Theatre 18001900 (Cambridge: Cambridge University Press, 1992), pp. 91-2; Macfarlane, Copyright, p. 30.

${ }^{30}$ Macfarlane, Copyright, p. 65.

${ }^{31}$ Stephens, Profession, p. 92.

${ }^{32}$ Ibid., p. 102.

${ }^{33}$ Ibid., p. 102.

${ }^{34}$ Ibid., p. 114.

${ }^{35}$ Seville, 'Copyright', p. 215.

${ }^{36}$ Stephens, Profession, p. 95.

${ }^{37}$ Jane Stedman, 'Theatre', in J. Don Vann and Rosemary T. VanArsdel (eds), Victorian Periodicals and Victorian Society(Aldershot: Scolar Press, 1994), p. 168.

${ }^{38}$ Elwin, Charles Reade, pp. 36-7, 53, 138; Reade, Eighth, pp. 67-123.

${ }^{39}$ Reade, Eighth, pp. 81, 110.

${ }^{40}$ Reade, Eighth, p. 87.

${ }^{41}$ Ibid., p. 104.

${ }^{42}$ Ibid., pp. 121-2

43 'Dramaticus', 'The Drama and Things Theatrical', Morning Chronicle, 16 February 1857, p. 6.

${ }^{44}$ Reade, Eighth, pp. 106-115.

${ }^{45}$ Ibid., p. 112.

${ }^{46}$ Ibid., p. 112.

${ }^{47}$ Ibid., p. 112. 
${ }^{48}$ Quoted in Ronan Deazley, (2008) 'Commentary on International Copyright Act 1852 ', in L. Bently \& M. Kretschmer (eds), Primary Sources on Copyright (14501900), www.copyrighthistory.org. Identifier: uk_1852

${ }^{49}$ [Brander Matthews], 'The Dramatisation of Novels, Longman's Magazine, October 1889), p. 596.

${ }^{50}$ Matthews, 'Dramatisation', p. 594.

${ }^{51}$ Elwin, Charles Reade, p. 142.

${ }^{52}$ Isabella Alexander, Copyright Law and the Public Interest in the Nineteenth Century (Oxford: Hart, 2010), p. 221.

${ }^{53}$ Elwin, Charles Reade, p. 143.

${ }^{54}$ Fawkes, p. 148.

${ }^{55}$ Charles Reade, 'Foul Play', Once a Week, 22 August 1868, pp. 151-60.

${ }^{56}$ Michael Tilby notes that the term for adaptation in the French journal Le Charivari in the 1850s was 'empruntée de première main' - borrowing at first hand conveys the possibility of more convoluted degrees of distance - 'A Miser's Daughter: Awareness of Balzac's Eugénie Grandet in Nineteenth-century England', Revue de Littérature Comparée 343 (July-September 2013), p. 279.

${ }^{57}$ Reade, 'Foul Play', p. 155.

58 Ibid., p. 152.

${ }^{59}$ Ibid., p. 153.

${ }^{60}$ Ibid., p. 153.

${ }^{61}$ Ibid., p. 154.

${ }^{62}$ William A. Brady, Showman (New York: E. P. Dutton, 1937), pp. 68-71. On the dispute with Daly, see Fawkes, pp. 172-4.

${ }^{63}$ Brady, Showman, pp. 68-9.

64 'Theatre Royal, Westminster', The Times, 29 January 1863, p. 10.

${ }^{65}$ Eaton Sylvester Drone, A Treatise of the Law of Property of Intellectual

Productions in Great Britain and the United States (Boston: Little, Brown, 1879). On Drone see Mark Rose, Authors and Owners: The Invention of Copyright (Cambridge Mass: Harvard, 1993), p. 132.

${ }^{66}$ Quoted, Drone, Treatise, pp. 199, 659.

${ }^{67}$ Townsend Walsh, The Career of Dion Boucicault (New York: Benjamin Blom, 1915), p. 103.

${ }^{68}$ Louis James, Fiction for the Working Man: 1830-1850 (London: Oxford University Press, 1963), p. 47; Ian Haywood, The Revolution in Popular Literature: Print, Politics and the People, 1790-1860 (Cambridge: Cambridge University Press, 2004), p. 133.

${ }^{69}$ Robert J. Kirkpatrick, 'George Berger and His Sons, 1796-1868', Yesterday's Papers, Friday Aug 1 2014, http://john-adcock.blogspot.com.au/2014/08/georgeberger-and-his-sons-1796-1868.html. Accessed 08.08.15

70 'Arrah-na-Pogue; or, the Wicklow Wedding', London Herald, 29 April 1869; 6 May 1865; 13 May 1865; 20 May 1865.

${ }^{71}$ National Archives, Kew, C16/251/B146, Bill of Complaint, Boucicault v. Berger, 6 May 1865, p. 3. Boucicault's own copies of this document, including his lawyer's draft, are in the University of Kent, Calthrop collection, uncatalogued deedbox marked FLJ.

72 Ibid., p. 8.

73 Ibid., p. 8-9.

${ }^{74}$ Bill of Complaint, pp. 4-6; 'Boucicault v. Berger', The Times, 12 May 1865, p. 10. 
75 Bill of Complaint, p. 3.

76 'Copyright of “Arrah-na-Pogue"”, Era, 14 May 1865, p. 11.

77 'Boucicault v. Berger', The Times, 12 May 1865; Carew, Invoice.

${ }^{78}$ Carew, Invoice, pp. 7-14.

${ }^{79}$ James L. Huffman surmises that House's contribution to Arrah was substantial, but more likely is a nominal input entitling him to register the play in New York for Boucicault, a non-citizen. A Yankee in Meiji Japan: the Crusading Journalist Edward H. House (Lonham: Rowman and Littlefield, 2003), p. 37. The Era reported that 'a few lines of the drama were written by an American gentleman, that the copyright in this city might be secured', 'American Theatricals', Era, 4 June 1865, p. 10.

${ }^{80}$ Oxford Dictionary of National Biography, s.v. 'Cairns, Hugh McCalmont'; Carew, Invoice, pp. 1-4.

${ }^{81}$ Dion Boucicault, Arrah-na-Pogue in David Krause (ed.), The Dolmen Press Boucicault (Dublin: Dolmen Press, 1964), p. 150. 